\title{
Correction to: Enhancement of needle visualization and localization in ultrasound
}

\author{
Published online: 11 January 2021 \\ (c) CARS 2021

\section{Correction to: \\ International Journal of Computer Assisted Radiology \\ and Surgery \\ https://doi.org/10.1007/s11548-020-02227-7}

Parmida Beigi ${ }^{1}$ - Septimiu E. Salcudean ${ }^{1} \cdot$ Gary C. $\mathrm{Ng}^{2} \cdot$ Robert Rohling ${ }^{3}$

The original version of this article unfortunately contained a mistake. The presentation of Table 1 was incorrect. The cell of "Steerable/Robot-assisted needles" should shift one column to the right.

The original article has been corrected.

The original article can be found online at https://doi.org/10.1007/ s11548-020-02227-7.

$\triangle$ Parmida Beigi parmidab@ece.ubc.ca

1 Electrical and Computer Engineering Department, University of British Columbia, Vancouver, BC, Canada

2 Philips Ultrasound, Bothell, WA, USA

3 Electrical and Computer Engineering Department and Mechanical Engineering Department, University of British Columbia, Vancouver, BC, Canada 


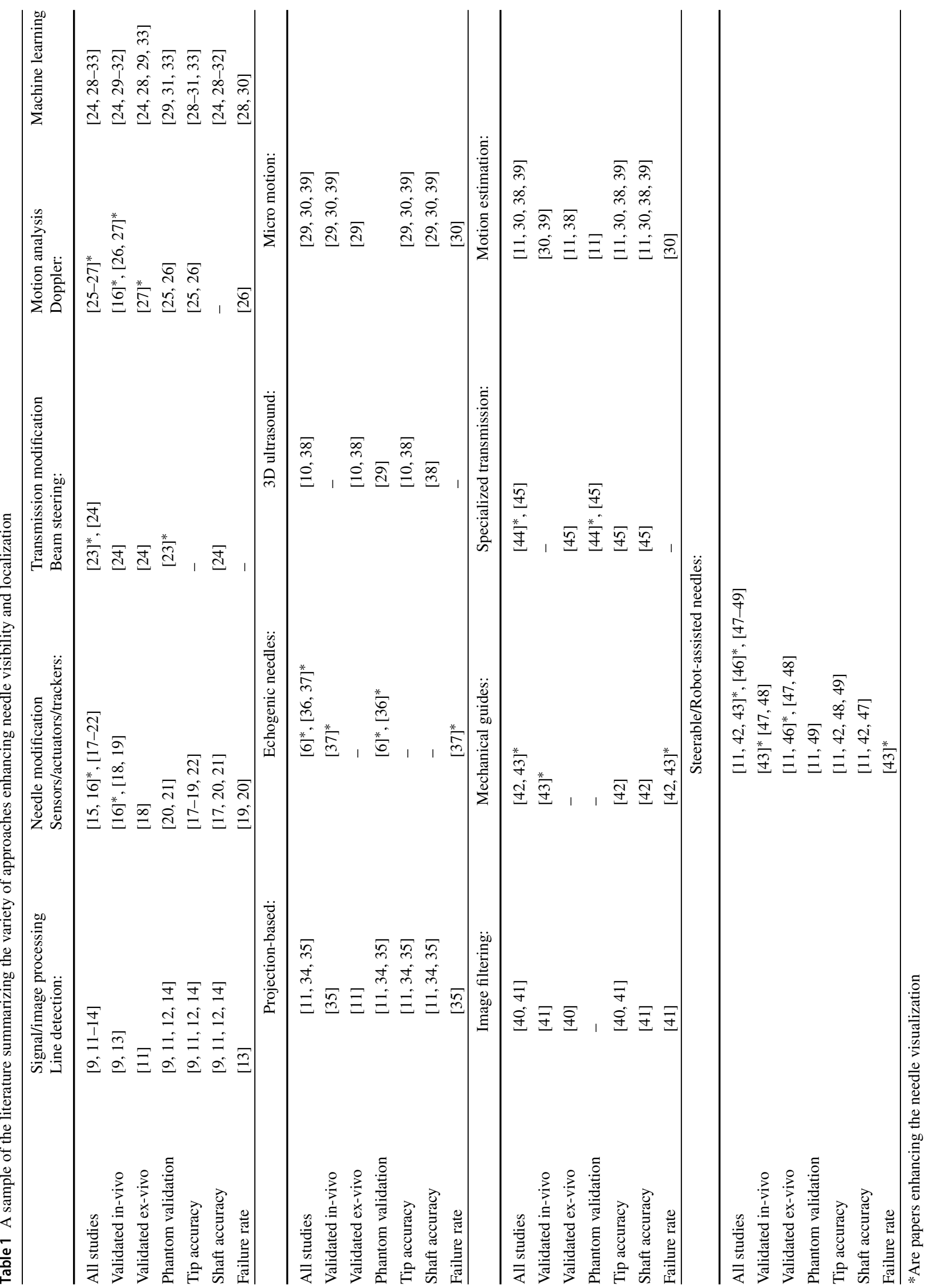


Publisher's Note Springer Nature remains neutral with regard to jurisdictional claims in published maps and institutional affiliations. 